\title{
REGIONAL INNOVATION FOR SUSTAINABLE DEVELOPMENT: AN AUSTRALIAN PERSPECTIVE
}

Jerry COURVISANOS 1

Centre for Regional Innovation and Competitiveness,

School of Business

University of Ballarat, Australia

Research Network on Innovation

j.courvisanos@ballarat.edu.au

\section{THE INNOVATION POLICY GAP}

Traditional private and public innovation policies aim to bridge the gap between incubation of the invention and commercialisation of the innovation (Jolly, 1997). The private sector seeks competitive advantage through innovation management by technological advancements (e.g. R\&D, knowledge acquisition) and collaborations (e.g. strategic alliances, cluster development). The public sector seeks to provide support to the private sector to overcome market failure in the corporate effort to bridge the innovation gap. Optimal resource allocation is the objective in effectively managing to bridge this innovation gap. As a crucial canon of mainstream neo-classical economics, this resource optimality for invention ensures maximum economic growth, and by implication, maximum economic welfare (Arrow, 1962). Using perfect competition as the benchmark, neo-classical economics sees mobile financial capital and human resources, together with low cost public dissemination of technical knowledge, leading to the transition from

1. Acknowledgement: Thanks to Ainsley Jolley, Centre of Strategic Economic Studies (CSES), Victoria University (Melbourne, Australia) for many research documents and long stimulating discussions in February-May 2007 on the issues of climate change during my professional development leave at CSES. I am also indebted to Francis Munier for valuable comments on the previous version of this paper; however, the author alone is responsible for any controversial opinions or remaining errors.

$n^{\circ} 3$ - Journal of Innovation Economics - 2009/1 
invention to successful innovation by way of appropriate regional locations (Auerswald and Branscomb, 2003, p. 86-7).

Two concerns arise with the neo-classical perspective of the innovation policy gap which forms the basis of this paper. One is the link between optimality and maximising economic welfare. The other is the automatic regional response to innovation activity. Both are contested and an alternative framework is outlined to address the innovation policy gap. Australia provides the context for this discussion.

Traditional innovation policy based on optimal economic growth has failed to deliver maximum social welfare in regional areas across the world. In fact, regional economies face serious environmental challenges with the scientific evidence clearly identifying greenhouse warming (or $\mathrm{CO}_{2}$ emissions) as the cause of significant climate change over the next fifty years. For example, the Garnaut Climate Change Review (Garnaut, 2008a) states that Australia is likely to be more exposed to the impacts of climate change than other developed economies due to four factors: (i) dry and variable continent, (ii) major agricultural base, (iii) terms of trade sensitive to Asian climate change impacts, (iv) fragility of nearby highly exposed developing economies. The first two factors point directly to the agricultural and regional economic core of Regional Australia and its ability to adapt in meeting the climate change challenge. Thus the focus of this paper is on an alternative innovation policy framework for agricultural and regional economic development that directly addresses most effectively climate change. This challenge is particularly crucial in Australia because, along with USA and Canada, current $\mathrm{CO}_{2}$ emissions are four times the global per capita average (Garnaut, 2008b, p. 31).

As an eminent economist, Garnaut (2008a) recognises the need for investment in the transition to a low-emissions economy. He argues that this transition can only occur through technological innovation, but how to bring about this transition quickly and effectively is the major policy issue. In his report Garnaut regularly mentions market failures as significant constraints on generating the market signals for optimal innovation-based transition. Yet, as a mainstream economist, Garnaut sees the market optimality approach to the innovation policy gap as the only path to transition ${ }^{2}$. Unfortunately, this market optimality is the same economic approach that has been used (and failed) over the last century in Australia to address environ-

2. See for example Garnaut (2008a, p. 426) where he states: “...market failures that impinge on the efficient and competitive functioning of markets for new ideas and technologies are likely to result in suboptimal levels of investment in innovation." 
mental issues like river salination, water shortage, and lack of establishment of non-fossil fuel energy.

Mainstream environmental economics and more recent ecological economics have the same optimality approach, and this is seen as the conventional wisdom to sustainable development to which no alternative framework is identified ${ }^{3}$. Optimality is strongly represented by economic development policies of international institutions like the IMF and the World Bank, antiinflation and budget restraint policies of independent central banks, and market deregulation policies of western democracies; all which by late 2008 combined to usher in a major recession stemming from the Global Financial Crisis (GFC) ${ }^{4}$. From the context of this paper, conventional wisdom is also strongly embodied in cost-benefit analysis to unresolved significant environmental issues of the type identified in Australia above. All these optimalitybased policies argue that this allows the private decision maker at a decentralised local level to incorporate costs as a marginal adjustment to the scale and form of any investment or spending decision with the objective of achieving a stable optimal (equilibrium) outcome. Through this approach, the innovation policy gap is bridged using private sector initiative financially and technically dependant on corporate investment decisions; and public sector support aimed to address any market failures arising from private sector investment.

The aim of this paper is to outline a challenge to this conventional framework with respect to sustainable agricultural and regional development. There is an alternative framework that allows a more effective transition to a low-emissions economy; one that relies on cooperation, rather than competition and conflict, to bridge the innovation policy gap and deliver ecologically sustainable innovation (or eco-innovation ${ }^{5}$ ). Lavoie (2006) identifies post-Keynesian heterodoxy as the alternative economic paradigm that adopts the cooperative model of economic development. However, Lavoie does not tackle the way that this paradigm can be used to develop a climate change framework towards a low-emissions economy. The task here is to develop such an eco-innovation policy framework for regional economies.

From Stilwell (1974, p. 195), a region is delineated as a community of interests with social cohesion and ecological unity. Social cohesion tends to

3. The late John Kenneth Galbraith for more than four decades, beginning with Galbraith (1958), railed against what he called the "conventional wisdom" from where at that vantage point any alternative was difficult to contemplate.

4. For critical analyses of mainstream economic policies and their resulting impact on the GFC, see Kregel (2008).

5. Van Berkel (2007a) defines "eco-innovation" as “...environment-informed and -driven improvements and innovations in products, services and processes that deliver more value to producers and/or consumers while progressively reducing net environmental impacts." 
support conventional wisdom, while on the other hand; ecological unity identifies strong environmental concerns that characterise a region. Apprehension exists in regions as they try to resolve this tension between conservative economic policies and conservation of the environment. The alternative framework provides a feasible resolution to this tension.

The next section of this paper outlines the conventional framework derived from the neo-classical economics and argues why the optimality approach will remain powerless to meet directly the climate change innovation challenge in regional economies. The following section adopts the alternative satisficing approach to develop an "eco-sustainable framework" for innovation policy in regional economies. This "eco-sustainable framework" is an attempt to set a policy framework for regionally-based economic development with consistent and workable public policy tools that encourage and support entrepreneurial innovation that is greenhouse ecologically congruent, and enacted by "ecopreneurs" (Schaper, 2005). The paper then outlines practical applications in regional communities of this framework using concrete examples of ecological-based innovation strategies. Finally, the paper examines the research and policy implications of this alternative framework for a complete sustainable development innovation policy that bridges the innovation policy gap while simultaneously addressing climate change.

Before going any further, sustainable development as a concept needs to be defined. Sustainable development became popular in 1987 after the contemporaneous publication of the Bruntland Report (WCED, 1987) and the environment pamphlet from the World Bank $(1987)^{6}$. In a general popular sense, sustainable development refers to economic development which "... meets the needs of the present without compromising the ability of future generations to meet their own needs." (WCED, 1987, p. 8) Many actions can be implemented in aiming towards this sustainable development concept by people, organisations (especially businesses) and governments; including energy efficiency, recycling, reduced planned obsolescence, improved mass public transport. All such actions will significantly address the climate change challenge. However, the underlying element that ensures sustainable development is the embodied technology in capital plant and equipment that enables the above actions to effectively prosper. The investment decision to support eco-innovation is the focus of this paper, and it employs the policy definition of sustainable development by Vercelli (1998, p. 268) where economic development is "...considered sustainable only when future generations are guaranteed a set of options at least as wide as that possessed by the current generation."

6. For a short account of the genealogy of the term, see Vercelli (1998, p. 267-8). 


\section{CONVENTIONAL FRAMEWORK}

The optimality policy approach drives the market-based conventional framework. In this framework, governments only set broad parameters within which the private sector operates. At the macroeconomic level it involves the setting of medium term targets on fiscal (for example, balanced budgets) and monetary (for example, minimum inflation) public policies, so that market forces can respond flexibly towards some stable market signals. With this comes a deregulatory agenda to foster private investment strategy that restructures away from protected mature industries to higher value added growth industries. The aim is to provide the investment decision makers with optimal efficient flow of market information and removing interventionist public policies that distort this optimal market information by increasing uncertainty and instability.

For environmental protection, the optimality approach recognises the efficiency gains from market-based instruments (for example, tradeable resource and emissions permits) over direct legal regulation (Godal and Klaassen, 2006). This allows the private decision maker to incorporate environmental costs as a marginal adjustment to the scale and form of the investment project, rather than just as a fixed regulated cost. From this overview of environmental economics, the overwhelming impression is one of microeconomic optimality. Research concentrates on valuation, types of instruments and resource constraints within particular regulatory regimes; allowing market signals to provide the appropriate environmental response (Eckersley, 1995, p. 15).

Sustainable development is merely assumed in the macro perspective as a future state that the economy reaches, but never analysed. Thus it can only be assumed that the appropriate environmental market signals will elicit allocatively efficient decisions (especially investment on capital stock) that will ensure sustainable development. Modelling hypothetical states provides neo-classical research with the basis to identify both cost-benefit valuations (for example, Considine and Larson, 2006 on "cap and trade" emission trading permits in the Acid Rain Program) and various obstructions (for example, Costello and Ward, 2006 on reluctance to invest in biodiversity protection) to the ideal sustainable development macro-state.

Ecological economics is the alternative to environmental economics, which has been dubbed "constrained market environmentalism" by Eckersley (1995). However, the investment process operates the same way as with mainstream economics but with an optimal scale of production where there is a balance of material-energy throughputs into the economy that maintains the flows from the ecosystem at a constant sustainable level. This is 
called steady-state, and is a pre-analytical optimal setting. Size of the investment projects is predetermined, yet there exists market-based encouragement to develop ecologically sustainable technology. Pearce and Atkinson (1993) begin discussion of steady-state with: "To do this we adopt a neoclassical stance and assume the possibility of substitution between 'natural' and 'man-made' capital" (p. 104, original emphasis). This analytical device by ecological economists assumes overriding steady-state optimality.

The optimality approach for ecological economics reaches its nadir with Sim (2006) where the neoclassical IS-LM macroeconomic model is extended to an IS-LM-EE model. This model includes an environmental equilibrium (EE) constraint that represents all interest rate-output combinations such that the economy's use of environmental services is exactly equal to the ability of the natural environment to supply them. Sim admits that "the model imposes a strong assumption that policymaker has perfect knowledge of what the environment constraint is...", but more puzzling is the implication that standard macroeconomic policy can induce supply of the natural environment. Varying the interest rate is a blunt inefficient macroeconomic policy instrument, so it is quite improbable that such rate variations can also induce appropriate environmental outcomes.

Vercelli (1998) argues cogently from first principles that uncertainty in the market makes any optimisation algorithm based on substantive (or unbounded) rationality impossible to be expressed in anyway that would have operational significance ${ }^{7}$. The elements of irreversibility and complexity that arise over real historical time imply that an adaptive procedural (or bounded) rationality is required. This means that the objective of sustainable development can only be achieved in a cumulative process of "learning by doing" and acquiring knowledge through implementation of acceptable adaptive (non-optimal) conventions and rules. Thus neither optimal approach to the environment, neo-classical or steady-state, can deliver sustainable development under conditions of market uncertainty. The result instead is the type of market failures described earlier by Garnaut which fail to provide adequate or even correct signals to induce eco-innovation ${ }^{8}$.

7. In fact Costanza and Daly $(1992$, p. 45) acknowledge that "[u]ncertainty itself is one of the critical factors that must be addressed in designing sustainable policies", suggesting that a natural capital depletion tax with some form of refundable assurance scheme to handle uncertainty. Problem is that this type of scheme will be subject to the same speculative pressures (and bubble booms) arising from capitalist uncertainty that occurs with any market-based policy strategy, resulting in GFC-type crises.

8. For a more detailed critique of the optimality approach in relation to the environment, see Courvisanos (forthcoming). 
From the regional perspective on the environment, market failures are (or attempt to be) resolved by broad national and state government interventions. However, such interventions come up against individual regional interests that militate against the required social cohesion and ecological unity which make interventions successful. In Australia the unresolved MurrayDarling Basin river salination is an example of how the concerns of specific regional interests along the whole Murray-Darling river system have not been addressed ${ }^{9}$. Market failures are addressed by establishing (often after community consultation) centralised 'top-down' adjustments to incentives, regulatory responses and improved information provision. All such actions can be useful, but regional interests (that are often divergent) can not be integrated towards a long-term community strategy ${ }^{10}$. The steady-state setting of ecological economics resolves the same issues by beginning with an optimal level and then uses that level to determine pricing and incentives. Uncertainties attached to resource availability and use, as identified by Adamson et al. (2005), make any such pre-analytic optimality constraints highly contingent on what authorities have been able to centrally determine. Regional interests are marginal to the optimality policy approach of both environmental and ecological economics, yet the real politics of the environment dictate that regional interests must be seriously dealt with.

The existing economic optimality paradigm is clearly inappropriate for responding effectively, timely and with regional awareness to crucial ecological concerns like greenhouse warming. A completely different economic framework, based on economic activity that is satisficing (under conditions of ecological uncertainty) rather than optimising (under conditions of calculable risk) is required to address climate change.

9. Goss (2003, p. 619) reports on the Murray-Darling River Basin that: "There is no agreed process for incorporating terrestrial biodiversity values at risk into a strategic response for drylandsalinity management. This is a public policy issue to be addressed." There is evidence that after 100 years, this public policy issue is finally being addressed with the COAG (Council of Australian Governments) Meeting of the 26 March 2008 agreeing to a new centralised water body and significant new Federal funding. However, as The Australian editorial on the following day states: "There is plenty of work yet to be done to decide what priority water projects will qualify for Commonwealth funding and how best to deal with the thorny issue of buying back water rights that have been over-allocated by state governments." (27 March 2008, p. 17)

10. This problem can be evidenced by a quote from a neo-classical economics study that argues "...that there is at least theoretical support for the notion of an optimal level of effort to devote to any community consultation activity." (Crase et al., 2005, p. 235, emphasis added) 


\section{ECO-SUSTAINABLE FRAMEWORK 11}

The following is presented as a specific detailed policy framework in the area of investment and innovation to a sustainable development future divorced of the optimality chimera. This is a two-step framework. First step is the provision of a bounded rationality (or satisficing) approach to the ecosystem and its links to the economy, which enables the creation of a cumulative iterative process towards sustainable development. Second step is to specify a policy strategy that is based on a "bottom-up" development of customs and norms around sustainable development, together with the requisite need for a cumulative growth in effective demand beginning with niche markets that have strong potential for demand expansion.

The policy framework aims to operate in a world of fundamental uncertainty (Davidson, 1991) and cumulative change (Kaldor, 1966) within the context of an innovative and sustainable environment. In terms of policy action, the framework has satisficing rather than optimising objectives at its base, as first espoused by Simon (1976) and since then adopted in behavioural analyses (Earl, 1989). Vercelli (1998) has cogently argued that the satisficing objective is required for efficiency and ethical reasons due to fundamental (or "hard") uncertainty, irreversible processes, and strategic learning. These reasons add up to systemic (and not market) failure and thus need a "designing rationality" that is "... aimed at designing a project of harmonious interaction between economic development and the natural environment and able to specify a strategy for its implementation." (Vercelli, 1998, p. 273)

As a policy framework, the political economy of the environment and investment needs to deliver an innovation strategy that has a long-run sustainable development scenario. The satisficing approach needs to be cumulative and iterative in the short-run, developing strong market share and effective demand for eco-innovations ${ }^{12}$. As more information and knowledge develops, the policy can be recalibrated towards a more sustainable long-run outcome. The framework sets up guiding principles for transition to sustainable development. Transition to a new path of economic development is known as a traverse which results in regime change by the adoption

11. This section is a revised and shortened version of Section 3 of Courvisanos (2005).

12. The hybrid (petrol-electric) car is a recent example of how effective demand ensures growing market share for an innovation. The problem is that this demand has come very belatedly out of large petrol price rises (market signals). The technology has been around for a long time, but there has not been any sustainable development planning process to introduce it earlier into capitalist economies. Current neo-liberal economic policies in advanced capitalist economies have prevented such satisficing planning procedures advocated in this paper. 
of (i) leading edge knowledge, (ii) new practices and (iii) different social organisations ${ }^{13}$.

The procedural framework begins with identifiable goals and then develops a strategy of public intervention in order to meet Vercelli's definition of sustainable development specified at the start of this paper ${ }^{14}$. Vercelli (1998, p. 274) in his conclusion outlines systemic failure and why long-run goals need to be established: One of the main reasons for the deterioration of environmental problems may be ascribed precisely to the myopia of economic agents increasingly obsessed by very short-run objectives. Short-run rationality produces a profound irrationality in the longer run. Only a broader long-run rationality may produce a process of sustainable development avoiding deep regrets.

The framework is based on the policy planning research of two traversebased economists. Together, the principles outlined from these two economists provide a paradigm shift in policies towards sustainable development. First is Adolph Lowe's supply side "instrumental analysis" as a way of using "instruments" to achieve agreed goals. Lowe (1976) establishes an analytical framework designed to enable rules of formal logic to be applied to economic cause and effect sequences over historical time. This framework is particularly aimed at using such cause-effect principles to set up state structural adjustment policies that can deliver a sustainable, equitable and ecologically supportive economic environment. This requires a shift away from existing technological solutions. Lowe calls this "...the search for the economic means suitable for the attainment of any stipulated end. To this procedure I have assigned the label of instrumental analysis." (Lowe, 1976, p. 11-12) 15 Forstater (1999) refers to this as "retroduction", a search procedure that works backwards from ends (in this case sustainable development) to means (in this case planning by - what Lowe labels - "regressive inferences").

Lowe argues that public policy instrumental analysis needs to concentrate on investment, which is the central element of any path to economic growth. Thus, any path to sustainable development must primarily concentrate on the type of capital stock that will carry, via effective demand, the

13. Examples of past transitions are: sailing to steam ships (1850-1914), gas to electric power (1878-1900), high to low death rates (1850-1900), residential coal to natural gas (1960-75), typewriters to computers (1970-90). The first three in the list co-evolved. See Geels (2005) for more details.

14. Goals, and targets, are crucial in any sustainable development planning project. Appreciation of the current systems that need to be transformed to achieve the appropriate sustainable development goals is a basic strategy in all ecological economics towards sustainability (see Hirsch Hadorn et al., 2006).

15. See the excellent exposition of Lowe's work in Oakley (1987). 
economy forward into the long-run. Analysis and evidence show that uncertainty by the "mistake-ridden private sector" causes investment instability and undermines any smooth effective path to economic growth (Courvisanos, 1996, p. 190-2) ${ }^{16}$. Further, Lowe explains that in market-based economic regions that lack relevant supportive physical and social infrastructure, there is insufficient order and coherence to impel the creation and market demand of innovative ecologically sustainable investment projects by the private sector. A state structural adjustment policy with appropriate infrastructure spending is needed to underpin the path to sustainable development.

Second is Michał Kalecki's demand side "perspective planning" (Kalecki, 1986). This is incorporated into the framework to provide an investment strategy that establishes motivation and voluntary conformity towards ecologically appropriate goals. A path of dynamic diffusion of new technology systems needs to be set up that is conducive to innovation in investment for a sustainable physical environment. This requires a long-run investment strategy with incrementally adjusting perspective planning. To achieve this it is necessary to specify practical short-run targets that induce, through effective demand, innovation in investment which eventually adds up to the long-run goals specified. Thus, a traverse to eco-sustainable regime change needs short-term feasible steps that fuse with targets set by the long-run investment strategy. Targets need to be monitored and plans must be assessed at regular short-term "end points" to see whether it is necessary to revise the goals and the strategy for reaching the broad based long-run scenario. A perspective plan with these goals is set up to form a specific investment program in consort with agreed ecological 'rules' that deliver the type of ecological sustainability determined by the instrumental analysis.

In Kalecki (1963)'s study of planning dynamics, there are two specific resource saving parameters that provide ecological-efficient criteria for rules formulation. One is the coefficient of real depreciation, the aim of which is to reduce this coefficient by proper maintenance and repair systems to equipment and infrastructures. The other is the coefficient of better utilisation of existing productive capacity. "Greater output may be obtained from existing plant due to improvements in the organization of labour, more economical

16. See also Richardson (1960) for details on lack of coordination in markets for investment and the systemic failures that this creates. The GFC that began in August 2007, and by early 2009 created the worst global economic recession since the 1930s, is the latest example of this instability due to "mistakes". For example, the former chairman of the Royal Bank of Scotland admitted that the bank made "a big mistake" in buying Dutch bank ABN Amro (The Age, 12 February 2009, Bus p. 2). Richardson goes on to specify how investment coordination through information agreements and industrial concentration can assist in developing micro-goals in policy oriented strategies which can significantly avoid such big "mistakes". 
use of raw materials, elimination of faulty products, etc." (Kalecki, 1963, p. 16), thus reducing the coefficient's value. Together these resource saving coefficients provide a sound basis for ecological rules within a sustainable investment strategy.

Barbier (1989) developed some ecologically sustainable rules that could form the basis of any Lowe-Kalecki planning framework. These rules deal with rates of both exploitation of natural resources and generation of wastes that specific ecosystems can assimilate for long-run "carrying capacity" sustainability. The problem is that different stakeholders (or interest groups) in the economy use alternative critical load carrying capacity measures in relation to the ecosystem. Within the context of tourism, Hoffmann (1998) identifies three carrying capacity measures that can be applied to the ecosystem in general:

i. physical capacity as the absolute limit that a resource can cope with; ii. ecological or real carrying capacity as the level beyond which there are unacceptable ecological impacts for ecologists;

iii. social or effective carrying capacity as the level beyond which unacceptable change occurs in the production of the good or service in terms of overcrowding and altering social behaviour.

Large business interests tend to support (i). Small and local based businesses, public environmental bureaucracies and ecologists tend to support (ii). The direct service providers "on the ground" (for example: national park rangers, local environment groups, low impact ecosystem based services) tend to support (iii). Kalecki's resource saving coefficients can be applied to all three capacity measures.

The perspective planning framework needs to first set up a dialogue between all stakeholders on how to achieve a deeper ecosystem sensitive market in any region or country using structural adjustment policies that plan to alter the economic base of that area. The aim is investment, not in "end of pipe" solutions to the ecosystem, but in an innovative proactive strategy that significantly alters the operation of the economy using all the tools available in the new information and communication technologies (ICT). This requires understanding of the possible means to develop the economy with ICT investment and an appreciation of the value of all three carrying capacity indicators as rules for monitoring, evaluating and developing each stage in the plan. Networking between all the stakeholders over the goals, means and their assessment must be rapid and continuous. Then processes need to be arranged where constructive dialogue concentrates on the means of achieving the goals based on the data available and rules used to 
assess this data. Once an investment plan has been developed, there must be continual re-evaluation of these rules over time so that they are not static, but instead reflect the latest innovative technological changes. This ensures the constrained investment strategy is flexible and adaptable.

When setting up rules within either the planning process (e.g. low-emission public transport system), or regulating the market (e.g. emissions trading scheme), Hodge (1995, p. 56) explains that to have confidence in the effectiveness of these rules "... any prescriptions will have to embrace a wide range of capital assets and precautionary rather than optimising approaches have to be adopted." This supports the satisficing rather than the optimising approach to sustainable development. An eco-sustainable framework can provide a level of confidence that the rules can be adhered. Such confidence induces innovation in investment, leading to revisions both in carrying capacities and economic growth for future iterative re-evaluations of the perspective plan. This cumulative and feedback process has the ability to establish precautionary rules to effectively meet the goal of sustaining the ecosystem, while regularly evaluating and revising the rules for getting there.

Since it is impossible to define with any certainty what sustainability requires, a risk-averse investment strategy needs to be initially introduced, and not based on a static optimising (and optimistic) scale of production. This clearly points to the use of the effective carrying capacity rate as the critical ruling measure. Over time what sustainability requires is a "shifting target" that depends on new information and technology becoming available and on changing attitudes and expectations adopted by the generation that has democratic public control (Hodge, 1995, p. 56). This democratic control implies grassroots input from the people who understand and operate within the fragile ecosystem together with ability to influence directly the goals and means used to develop the ecologically sensitive economy. This strategy rejects superficial notions of democracy as some occasional voting for representative leaders. Instead, this strategy embraces a more participatory process that requires significant appreciation of the life support systems that need to be taken into account (see Hirsch Hadorn et al., 2006).

In achieving the sustainability objective, Hoffmann (1998) argues for strategic alliances and innovation networks between stakeholders. There are vast ideological and business differences between all stakeholders, especially with regards to their support for different carrying capacity rules. Under these conditions, it seems networks across all stakeholders could be very tenuous. Democratic control requires networking across all parties with specific details of the stipulated sustainable ends, but then decisions on the plans and implementation must be arrived at by majority support. The minority in 
the network, even if more economically powerful, must accept the need to act within the bounds of the majority based plan and policies.

This eco-sustainable framework provides cumulative effective demand growth based on sustainability rules that aim to establish certainty within which innovative investment by the private sector can flourish. Demand growth is managed and nurtured by strong strategic niche markets in ecoinnovations. Continual iterative re-evaluation of investment plans encourage further innovation that lead to more acceptable and internationally competitive sustainability rules. This creates self-reinforcing internal dynamics that induce strong international competitiveness, growth and employment.

In summary, this framework has three crucial elements:

1. Cumulative effective demand that establishes a strong market.

2. Ecological rules that ensure capital investment is resource saving with long-run carrying capacities which are sustainable.

3. Perspective, flexible and risk-averse investment strategy with democratic control.

\section{APPLICATION TO REGIONAL ECONOMIES}

Although the complete eco-sustainable framework is not in evidence anywhere, elements of it can be seen in various regions/nations in developed economies. There are many practical regional-based implementation strategies currently in existence that are appropriate for the type of alternative ecosustainable framework proposed here. Experience from such diverse practical environmental strategies can be incorporated into the proposed eco-sustainable innovative framework. It is this framework, and not merely a collection of diverse practical strategies, that will deliver regime change to effectively counter climate change. Regime change comes from "top-down" planning and regulation by government policy. Then, entrepreneurial "bottom-up" eco-innovation initiatives by business and other interest groups can establish niche demand solutions that grow with the support of this government policy. The specific mix of top and bottom depends on the particular region and the embeddedness in a region of current practices. This is where regional innovation comes into its own.

By examining the experience of instituting regional innovation in the peripheral region of Wales, Morgan (1997, p. 498) recognises the role of topdown as setting the direction and bottom-up in driving demand. Success of such an integrated mix depends on receptivity to such niche market developments depending on the "nuances" of the specific region under consideration. 
Morgan (1997, p. 496) argues that organisations need to modify their internal routines consistent with these regional nuances by promoting at least three types of competence: technological (mastering technical aspects), entrepreneurial (integrate technologies with organisational strategy), and learning (ability to absorb and use information). Organisations' receptivity to the stakeholders in the region - from government regional development officers to competitors and customers (both actual and potential) - is central to developing such competences.

From the experience of working for the US Environmental Protection Agency, Norton (2005) diagnoses the shortcomings of US environmental policy. Essentially, Norton's argument is that the US policy lacks both a problem-solving method and a willingness to evaluate and improve on (or discard) policy experiences. This indicates a lack of iterative learning competence, despite USA's strength in the other two competences (Morgan, 1997, p. 492). To overcome this problem, Norton advocates a social science research method to complement the dominance of neo-classical economics, this being an iterative process of experiential learning from appropriate practice and then adapting towards a better outcome. Norton's pragmatic strategy embodies procedural rationality, but is deficient of a long-run satisficing objective of a stipulated sustainable goal that all environmental policies need to embrace.

The European experience in transition to sustainable development by eco-innovations is much deeper than anywhere else on the globe and is much more pragmatic and iterative than USA, but much less entrepreneurial. In mainland Europe, there is a strong optimistic top-down drive to achieve ecological goals. René Kemp has researched bottom-up European entrepreneurial regionally-based eco-innovations in niche markets, notably in transportation (Kemp and Rotmans, 2004), energy (Kemp and Loorbach, 2005), and waste management (Kemp and Andersen, 2004). Kemp sees these innovations as being influenced by top-down public policy initiatives through the use of markets, hierarchy and institutions. Market influence is when permissible limits are set and the market establishes permit price (e.g. regulated emissions trading scheme ${ }^{17}$ ). Hierarchical influence is when economic activities are centrally coordinated (e.g. urban transport planning ${ }^{18}$ ). Institutional influence is strongly regional through setting standards, establishing trust, creating networks and sharing beliefs (Parto, 2005). Together the three public policy influences form the essential transition management tools.

17. See Ellerman and Buchner (2007).

18. See City Of London (2007) 
As Norton (2005) notes, it is the iterative feedback strategy that can revitalise local communities. In Australia, the regional (non-metropolitan) communities are physically closer to the ecosystem and have definite (sometimes very contrasting) values that allow potentially effective bottom-up voices to be heard in the development process. Because of this specific environment, the innovation system in Australia has historically "avoided top-down direction setting in the research sector, with a preference for allowing organisations to exercise considerable autonomy in deciding what research to pursue." (OECD, 2005, p. 326) Such a long standing institutional set up allows for strong bottom-up iterative feedback. The best example of this is CSIRO, a key institution in Australia's innovation system, which began as a public $R \& D$ organisation dealing with fundamental agriculture related science to improve productivity ${ }^{19}$. This involved central $R \& D$ laboratories, but also a large extensive network of advisory field officers throughout the rural farming communities to offer practical regional advice in implementing new innovations and providing feedback to central laboratories. CSIRO has now extended its research into " 20 research areas, including agribusiness, health, environment, natural resources, ICT, manufacturing, services, sustainable minerals and energy...[with] a stronger focus on commercialisation of its research" (OECD, 2006, p. 312).

Australian Governments have been influenced strongly by neo-classical economists in adopting the neo-liberal innovation policy stance of shortterm market-driven prioritisation and not "picking winners". Extension of CSIRO's research areas and its focus on commercialisation reflect this market-driven orientation over the last 20 years. This has been to the detriment of any long-run top-down planning and regulation. Detailed specific research direction by government planning should be avoided and experts need to follow their own judgement, however, broad innovation directions need a satisficing objective. In the present circumstances this needs to be eco-innovation. Previous examples of the Australian Government recognising systemic (not merely market) failure and responding by 'picking' successful broad directions to encourage innovation can be listed as: CSIRO (in agriculture), Screen Australia (previously the Australian Film Commission, AFC), Australian Institute of Sport (AIS), and the Pharmaceuticals Partnerships Pro$\operatorname{gram}\left(\mathrm{P}^{3}\right)^{20}$.

19. See Collis (2002) for the history of the CSIRO (Commonwealth Scientific and Industrial Research Organisation).

20. For economic evaluation of these innovation policy directions see the following; on CSIRO see Hastings (1977), on AFC see Molloy and Burgan (1993), on AIS see Hogan and Norton (2000), on $\mathrm{P}^{3}$ see Deloitte Insight Economics (2008). 
Political economy tension occurs between Australia's short three-year electoral cycle that encourages short-term populist policy making and implementing a long-run strategy which requires bipartisan support. In times of national crisis bipartisan support for regime change via new innovation policy direction can emerge; for example CSIRO emerged after the 1890s Depression to develop agriculture and AIS emerged after no gold medals from the 1976 Montreal Olympic Games. However, such occurrences are rare, and even at the time of writing in March 2009, no bipartisan policy has emerged out of the GFC. Dyson (2009) argues that clean technology needs to be the new innovation direction for Australia out of the GFC. ${ }^{21}$ The eco-sustainable framework developed above, with its strong regional focus, provides the policy pathway for this direction.

In the eco-sustainable framework, any regional bottom-up initiatives should dovetail in a co-ordinated manner into an overall national top-down sustainable development agenda. This agenda should aim to reflect agreed global environmental protocols and regulations. Like Russian dolls, each smaller regional focus must neatly fit into the larger regional focus. Given the uncertainty in the future, the 'fitness' is more on common strategy with different iterative paths of transition to ecological targets within specified long-term international protocols. These protocols need to gradually incorporate developing economies as their levels of economic activity begin to have significant global environmental implications.

Figure 1 summarises the argument of this paper in the grid and provides a flowchart of the investment planning process on the bottom. The left column has the three pillars of the eco-sustainable framework. The centre column sets out the criteria for sustainable development required in both public and private sector investment planning within specific institutional and cultural domains. The right column shows how specific Australian regionalbased practical greenhouse strategies for innovation have the potential to support the proposed investment plan. The bottom row is a flowchart which indicates how each column should interact. The flowchart is a practical procedure for a coherent planning process. This framework offers a cohesive plan for investment that allows specific strategies to induce eco-innovation. This then takes the strategies out of the environmental divisions of the public/private sectors and locates them in the central decision-making processes. Then, the environment is no longer a separate strategy, but instead a stipu-

21. Dyson (2009) supports this argument by noting that 20 years ago Australia was a leader in the first wave of clean energy innovations now powering the world. All this technology and its innovators exited Australia as neo-liberal short-term market priorities dominated the policy landscape. 
lated end that is integrated in the strategic management and planning of any (and every) organisation.

Focus now moves to identifying regional applications that appear in the right-hand column of Figure 1. These are all examples that have been appraised by other authors, and they are placed within the context of the eco-sustainable framework. Currently all such examples (and there are many more throughout Australia that are not mentioned here) make up a plethora eco-sustainable "patches" that are not connected together into some coherent patchwork. All the examples mentioned have developed strong regional niche markets, but for an effective transition to sustainability there is a need to have all three elements linked together with the investment criteria in the second column. This linking must first be at one region, and then extended to other regions with ties across regions. An example of linking the patches together to effect a regime change transition in the past was the automobile. What changed a quaint niche activity into the major transportation system of the $20^{\text {th }}$ Century was government planning of roads, traffic lights and related infrastructure, together with the business development of petrol stations, auto-mechanics, tow truck operations, road service and the like. Integration of such diverse activities occurred as public planning was linked to road carrying capacities, with flexible road developments that were evaluated in the context of user demand for the new innovation ${ }^{22}$. The greenhouse gas imperative requires the petrol-driven automobile to be placed in the "dustbin" of history, but technological lock-in is a powerful force which regime change must defeat.

Regional implementation examples identified in Figure 1 begin with ecological rules; one example is a business establishing ecological rules, while another example concentrates on communicating such rules. Pig Pen is a sustainable intensive pig farming operation in North East Victoria using the triple bottom line with a strong adaptive capacity over seven years and a tiny ecological footprint (Penniceard, 2007). ${ }^{23}$ This commercial operation is a pointer to a major shift required in agriculture in which new ecological agricultural rules are established. "The Break" Newsletter provides information throughout the broad cropping regions of Victoria and southern New South Wales on climate change and seasonal risk factors. This online newsletter has the basis for communicating new ecological rules and reducing uncertainty in a highly climate variable environment (Price et al., 2008).

22. For a history of the automobile and the environment around it, see Wachs and Crawford (1992). 23. Agriculture has a relatively large ecological footprint in Australia. "Greenhouse gas emissions from agricultural production represented approximately $16 \%$ of total national emissions in 2005 , a proportion higher than that of any other OECD country apart from New Zealand." (Department of Climate Change, 2008) 
Figure 1 - The Eco-sustainable Framework

\begin{tabular}{|c|c|c|}
\hline $\begin{array}{l}\text { Eco-sustainable } \\
\text { elements }\end{array}$ & $\begin{array}{l}\text { Investment } \\
\text { planning } \\
\text { criteria }\end{array}$ & $\begin{array}{c}\text { Regional-based implementation } \\
\text { strategies }\end{array}$ \\
\hline Ecological rules & $\begin{array}{l}\text { - } \quad \text { Sustainable long-run } \\
\text { carrying capacities } \\
\text { - } \quad \text { Resource-saving new capital } \\
\text { stock }\end{array}$ & $\begin{array}{l}\text { Develop and communicate } \\
\text { appropriate sustainability rules } \\
\text { [e.g. Pig Pen, "The Break"] }\end{array}$ \\
\hline Perspective planning & $\begin{array}{l}\text { - Iterative flexible ex-ante } \\
\text { planning } \\
\text { - Bottom-up monitoring and } \\
\text { evaluation }\end{array}$ & $\begin{array}{l}\text { Establish, monitor, evaluate and } \\
\text { adapt environmental policies } \\
\text { (e.g. CMAs, VCCAP) }\end{array}$ \\
\hline Cumulative effective demand & $\begin{array}{l}\text { - } \quad \text { Strong niche market base } \\
\text { - } \quad \text { Experience from current } \\
\text { eco-sustainable innovation-based } \\
\text { users }\end{array}$ & $\begin{array}{l}\text { Niche management of regional } \\
\text { network user-led activities [e.g. } \\
\text { Landcare, Coastcare, } \\
\text { SmartGreen] }\end{array}$ \\
\hline $\begin{array}{l}\text { Planning } \\
\text { framework }\end{array}$ & $\begin{array}{l}\text { Process of investment } \\
\text { strategy planning in } \\
\text { public and private } \\
\text { sectors }\end{array}$ & $\begin{array}{l}\text { Regional } \\
\text { networks } \\
\text { appropriating } \\
\text { investment } \\
\text { strategies }\end{array}$ \\
\hline
\end{tabular}

At the regional perspective planning level, two examples of iterative flexible planning, monitoring and evaluation are VCCAP and CMAs. Under the Victorian Climate Change Adaptation Program (VCCAP) an interdisciplinary team from the University of Melbourne and two Victorian state departments undertake research, communication and policy development for agricultural industries in the context of climate change problems (Griffin and Eckard, 2007). Natural Management Regions across Australia lead the cost-effective protection and enhancement of the land and water resources in network of 56 distinct regions under the National Action Plan for Salinity and Water Quality (NAP) and are evaluated in Head (2005). Water Catchment Management Authorities (CMAs) in Victoria implement the NAP and provide the basis for adaptive environmental policies.

Australia has been very successful at developing many strategic niche bases for eco-sustainable management which enable cumulative effective demand to be built for growing awareness in, and demand for, natural environment 'goods'. Probably the most successful one of these is Landcare, a national community-based network that is government and corporate-funded. Established in 1989, Landcare implements landscape improvement (e.g. plant trees) and develops a positive attitude to sustainable land management through education (Huthwaite, 2007). Community-focused, with the state playing little role in assigning priorities or resolving trade-offs, Campbell 
(1994) recognises the lack of a top-down institutional strategy as the strength in this participatory activity. This network strategy has been adopted by Coastcare to manage the coast, but with more state input from the Victorian Government. From another angle on strategic niche management, SmartGreen is a new initiative by the University of Ballarat and Ballarat Council to assist a cluster of small businesses in the Ballarat region to be more entrepreneurial and access new business opportunities from sustainable environmental policies and the development and delivery of environmental services. Some idea of the extent of success by such "ecopreneur" (Schaper, 2005) initiatives as SmartGreen can be discerned in Van Berkel (2007b) where he reviews the Cleaner Production and Eco-Efficiency initiatives from 30 Australian small firms that participated in these two eco-innovation government-funded programs.

\section{IMPLICATIONS}

The basic argument in this paper is that all economies need to undertake regime change from high-emissions to low-emissions. This transition to sustainable development requires a paradigm shift in the production and distribution of economic activity, and can only occur via eco-innovation. An optimising approach to this transition is rejected in favour of a satisficing approach under conditions of large market uncertainty that occurs in periods of structural change. The analytics of two economists who concentrated their efforts on understanding how economies go through regime change have been employed to develop this policy framework. The Lowe-Kalecki eco-sustainable framework provides a cumulative iterative process that encourages eco-innovation to meet short-run satisficing objectives that dovetail into long-run sustainability. The framework consists of a combination of three critical elements together with a nationwide systemic investment process strategy that funds and supports eco-innovation at all levels of society.

The previous section identified examples of regional eco-innovation and showed how they would fit into the eco-sustainable framework. Thus, aspects of the framework are already deployed around Regional Australia, but they are all small and disparate. What is missing is a coherent structure and pattern to all these diverse and ad hoc occurrences. Two regional implications emerge from the eco-sustainable framework. One implication is the adaptive governance strategy that regional authorities need to adopt towards global environment problems. This requires recognition of local development of customs and norms around sustainable development that create social cohesion and ecological unity. Conflicts will inevitable arise (e.g. local opposition to wind farms), but such conflicts can be overcome at the local 
level through the adaptive governance strategy to the satisficing objective outlined above. National and international protocols and regulations enable such localised conflicts to be resolved in a coherent manner consistent with sustainable development.

The second implication is based on the "Butterfly Effect" as it is applied to economic systems (Ormerod, 1998). ${ }^{24}$ This effect can be applied to small niche eco-innovations by recognising that local consequences will be amplified via flow-on diffusion effects in the evolution of the new sustainable development paradigm, but within the context of the agreed global/national ecologically sustainable rules and the perspective plan governing the new paradigm. As diffusion proceeds, learning takes place that improves the innovation in its adaptation to different regional circumstances. Over time the rate of diffusion will rise quickly (Rosenberg, 1972).

Research implications relate to adopting the eco-sustainable framework as a benchmark to monitor and evaluate the various regional programs and initiatives that develop. Rather than simply describing and critiquing a program, this eco-sustainable framework enables the researcher to find what are the elements of the program that support the new transition paradigm and what are the missing or negative features of a specific program that work to detract from the transition. It can also lead to an iterative process of identifying the strengths of a regional program that the current policy is not addressing, then the policy must adapt to allow the regional initiative to create a strong "butterfly effect". From the opposite angle, rates of diffusion of ecoinnovations will vary from region to region depending on economic, cultural and technological factors. Given the diversity of alternative sustainable activities (e.g. sources of energy like wind, solar, geothermal, tidal, biomass, nuclear, bio-fuels) such variety needs to be encouraged and supported in the perspective plan, if these activities are within the context of the paradigm transition that has been mapped out. Here the research effort must be to identify the diffusion of eco-innovations (technologies and activities) and focus on whether scarce resources are being used in the most effective methods for commercialisation. This is where researching the strength of regional input can more clearly identify commercial possibilities ${ }^{25}$.

24. The Butterfly Effect, proposed by Edward Lorenz in 1963, argues that the flapping of a butterfly's wing would cause a disturbance that becomes exponentially amplified so as to eventually affect large-scale atmospheric motion. Ormerod (1998) described the same effect by a biological experiment on ants, showing that an ant goes out and finds food which encourages others to follow it back to its source. The self-reinforcing mechanism with ants is very strong. From an evolutionary economics perspective, Ormerod applied this mechanism to economic activities at a local level to show both positive and negative outcomes.

25. For an example of how to use this eco-sustainable framework to analyse an environmental policy and the role of regional input, see Courvisanos and Jain (2006). 
The eco-sustainable framework is an approach that can be applied to any economy, using regional communities and their networks as the bulwark for democratically devising ecological rules in a nationally stipulated precautionary low-emissions economy target. Then, regions can strongly input into a national "perspective plan" with regional targets and creating strategic niche regional markets to implement these strategies. Critical mass for sustainable development is the objective. This is the specific approach to meeting the innovation policy gap that supports sustainable development through regional input and iterative learning. With the onset of the Global Financial Crisis and the most severe recession since the 1930s, the year 2009 provides basis for creative destruction of the old technological system and a shift to eco-innovation sustainable development by the framework set out in this paper. Bailing-out and supporting the mistaken-ridden discredited capitalists of the current energy inefficient technological system will only delay this shift. This new framework must be applied immediately.

\section{REFERENCES}

ADAMSON, D., QUIGGIN, J. and MALLAWAARACHCHI, T. (2005), Modelling basin level allocation of water in the Murray Darling Basin in a world of uncertainty, Murray Darling Working Paper MO5\#1, Brisbane, University of Queensland. Retrieved 5 May 2007, from:

www.uq.edu.au/economics/rsmg/WP/WPMO5_1.pdf

ARROW, K. (1962), "Economic welfare and the allocation of resources for invention", in Nelson, R. (ed.), The Rate and Direction of Inventive Activity, Princeton, Princeton University Press, p. 602-25.

AUERSWALD, P. E. and BRANSCOMB, L. M. (2003), "Start-ups and spin-offs: Collective entrepreneurship between invention and innovation", in Hart, D. (ed.), The Emergence of Entrepreneurship Policy, Cambridge, Cambridge University Press, p. 61-91.

BARBIER, E. (1989), Economics, Natural-Resource Scarcity and Development, London, Earthscan.

CAMPBELL, A. (1994), Landcare: Communities Shaping the Land and the Future, Sydney, Allen Unwin.

CITY OF LONDON (2007), Climate Change Action Plan, 27 February. Retrieved 2 May 2007, from:

www.london.gov.uk/mayor/environment/climate-change/ccap/index.jsp

COLLIS, B. (2002), Fields of Discovery: Australia's CSIRO, Crows Nest, NSW, Allen \& Unwin.

CONSIDINE, T. and LARSON, D. (2006), "The environment as a factor of production", Journal of Environmental Economics and Management, vol. 52 (3), p. 645-62.

COSTANZA, R. and DALY, H. (1992), "Natural capital and sustainable development", Conservation Biology, vol. 6 (1), p. 37-46. 
COSTELLO, C. and WARD, M. (2006), "Search, bioprospecting and biodiversity conservation", Journal of Environmental Economics and Management, vol. 52 (3), p. 615-26.

COURVISANOS, J. (1996), Investment Cycles in Capitalist Economies: A Kaleckian Behavioural Contribution, Cheltenham, UK and Brookfield, US, Edward Elgar.

COURVISANOS, J. (2005), "A post-Keynesian innovation policy for sustainable development", International Journal of Environment, Workplace and Employment, vol. 1 (2), p. 187-202.

COURVISANOS, J. and JAIN, A. (2006), "A framework for sustainable ecotourism: Application to Costa Rica", Tourism and Hospitality: Planning and Development, vol. 3 (2), p. 131-42.

COURVISANOS, J. (forthcoming), "Optimise versus satisfice: Two approaches to an investment policy in sustainable development", in Holt, R. (ed.), Post Keynesian and Ecological Economics: Confronting Environmental Issues, Cheltenham, UK and Northampton, US, Edward Elgar.

CRASE, L., DOLLERY, B. and WALLIS, J. (2005), "Community consultation in public policy: The case of the Murray-Darling Basin of Australia", Australian Journal of Political Science, vol. 40 (2), p. 221-37.

DAVIDSON, P. (1991), "Is probability theory relevant for uncertainty? A Post Keynesian perspective”, Journal of Economic Perspectives, vol. 5 (1), p. 129-43.

DELOITTE INSIGHT ECONOMICS (2008), Evaluation of the Pharmaceuticals Partnerships Program: Final Report, 22 May, Sydney, Deloitte Touche Tohmatsu.

DEPARTMENT OF CLIMATE CHANGE (2008), Greenhouse and Agriculture, Canberra: Australian Government, 5 April. Retrieved 20 August 2008, from:

www.climatechange.gov.au/agriculture/index.html

DYSON, J. (2009), "Power-up for clean technology", The Age, 1 April, Business Day p. 12. EARL, P. (1989), "Bounded rationality, psychology and financial evolution: Some behavioural perspectives on post-Keynesian analysis", in Pheby, J. (ed.) New Directions in PostKeynesian Economics, Aldershot, UK, Edward Elgar, p. 165-89.

ECKERSLEY, R. (1995), "Markets, the state and the environment: An overview", in Eckersley, R. (ed.) Markets, The State and The Environment: Towards Integration, Macmillan, South Melbourne, p. 7-45.

ELLERMAN, A. and BUCHNER, B. (2007), "The European Union emissions trading scheme: Origins, allocation, and early results", Review of Environmental Economics and Policy, vol. 1 (1), p. 66-87.

FORSTATER, M. (1999), "Working backwards: Instrumental analysis as a policy discovery procedure", Review of Political Economy, vol. 11 (1), p. 5-18.

GALBRAITH, J. K. (1958), The Affluent Society, Boston, Houghton Mifflin.

GARNAUT, R. (2008a), The Garnaut Climate Change Review: Final Report, Port Melbourne, Cambridge University Press.

GARNAUT, R. (2008b), Garnaut Climate Change Review: Interim Report to the Commonwealth, State and Territories Governments of Australia, Melbourne, Victorian Department of Premier and Cabinet, February.

GEELS, F. (2005), Technological Transitions and Systems Innovations: A Co-evolutionary and Socio-Technical Analysis, Cheltenham, UK and Northampton, US, Edward Elgar. 
GODEL, O. and KLAASSEN, G. (2006), "Carbon trading across sources and periods constrained by the Marrakesh Accords", Journal of Environmental Economics and Management, vol. 51 (3), p. 308-22.

GOSS, K. (2003), "Environmental flows, river salinity and biodiversity conservation: Managing trade-offs in the Murray-Darling Basin”, Australian Journal of Botany, vol. 51 (6), p. 619-625.

GRIFFIN, T. and ECKARD, R. (2007), "Victorian Climate Change Adaptation Program (VCCAP)", paper presented at Greenhouse 2007 Conference, Sydney, 2-5 October.

HASTINGS, T. (1977), The Economics of Public Sector Scientific Research in Australian Agriculture, unpublished PhD. thesis, Faculty of Economics, University of Adelaide, Australia, July.

HEAD, B. (2005), "Participation or co-governance? Challenges for regional natural resource management", in Eversole, R. and Martin J. (eds), Participation and Governance in Regional Development: Global Trends in an Australian Context, Burlington, VT, Ashgate, p. 137-54.

HIRSCH HADORN, G., BRADLEY, D., POHL, C., RIST, S. and WIESMANN, U. (2006), "Implications of transdisciplinarity for sustainability research", Ecological Economics, vol. 60 (1), p. 119-28.

HODGE, I. (1995), Environmental Economics: Individual Incentives and Public Choices, London, Macmillan.

HOFFMANN, H. B. (1998), "The tourism industry and the evolving need for strategic alliances: A DoZana perspective”, paper presented at The Seventh International Greening of Industry Network Conference, Rome, November.

HOGAN, K. and NORTON, K. (2000), "The 'price' of Olympics gold”, Journal of Science and Medicine in Sport, vol. 3 (2), p. 203-18.

HUTHWAITE, P. (2007), "Landcare and climate change: A regional perspective", paper presented at Greenhouse 2007 Conference, Sydney, 2-5 October.

JOLLY V. K. (1997), Commercializing New Technologies: Getting from Mind to Market, Boston: Harvard Business School Press.

KALDOR, N. (1966), Causes of the Slow Rate of Economic Growth in the United Kingdom, Cambridge, Cambridge University Press.

KALECKI, M. (1963), Introduction to the Theory of Growth in a Socialist Economy [in Polish], reprinted [in English] in J. Osiatyński (ed.) (1993), Collected Works of Michat Kalecki, Volume IV: Socialism - Economic Growth and Efficiency of Investment, Oxford, Clarendon Press. KALECKI, M. (1986), Selected Essays on Economic Planning, Cambridge, Cambridge University Press.

KEMP, R and ANDERSEN, M. M. (2004), "Strategies for eco-efficiency innovation", Strategy paper for the EU Informal Environmental Council Meeting, 16-18 July, Maastricht, VROM, Den Haag, The Netherlands.

KEMP, R. and LOORBACH, D. (2005), "Dutch policies to manage the transition to sustainable energy", in F. Beckenbach, U. Hampicke, C. Leipert, G. Meran, J. Minsch, H. G. Nutzinger, R. Pfriem, J. Weimann, F. Wirl and U. Witt (eds), Jahrbuch Ökologische Ökonomik: Innovationen und Nachhaltigkeit, Marburg, Metropolis Verlag, p. 123-150. 
KEMP, R. and ROTMANS, J. (2004), "Managing the transition to sustainable mobility", in B. Elzen, F. Geels and K. Green (eds), System Innovation and the Transition to Sustainability: Theory, Evidence and Policy, Cheltenham, UK and Northampton, US, Edward Elgar, p. 137-67.

KREGEL, J. (2008), Changes in the U.S. Financial System and the Subprime Crisis, Working Paper $n^{\circ}$ 530, The Levy Economics Institute of Bard College, New York, April.

LAVOIE, M. (2006), Introduction to Post-Keynesian Economics, Basingstoke, UK and New York, USA, Palgrave Macmillan.

LOWE, A. (1976), The Path of Economic Growth, Cambridge, Cambridge University Press.

MOLLOY, S. and BURGAN, B. (1993), The Economics of Film and Television in Australia, Sydney, Australian Film Commission.

MORGAN, K. (1997), "The learning region: Institutions, innovation and regional renewal", Regional Studies, vol. 31 (5), p. 491-503.

NORTON, B. (2005), Sustainability: A Philosophy of Adaptive Ecosystem Management, Chicago, University of Chicago Press.

OAKLEY, A. (1987), "Introduction: Adolph Lowe's contribution to the development of a political economics", in Lowe, A. Essays in Political Economics: Public Control in a Democratic Society, New York, New York University Press.

OECD (2005), Governance of Innovation Systems: Volume 2 Case Studies in Innovation Policy, Paris, OECD.

ORMEROD, P. (1998), Butterfly Economics: A New General Theory of Social and Economic Behavior, London, Faber \& Faber.

PARTO, S. (2005), "Economic activity and institutions: Taking stock", Journal of Economic Issues, vol. 39 (1), p. 21-52.

PEARCE, D. and ATKINSON, G. (1993), "Capital theory and the measurement of sustainable development: An indicator of 'weak' sustainability", Ecological Economics, vol. 8 (2), p. 103-8.

PENNICEARD, C. (2007), "A new sustainable farming paradigm”, paper presented at Greenhouse 2007 Conference, Sydney, 2-5 October.

PRICE, D., SOUNNESS, C. and GREY, D. (2007), “The Break' newsletter: A catalyst for communicating climate and risk management information throughout the agricultural community”, paper presented at Greenhouse 2007 Conference, Sydney, 2-5 October.

RICHARDSON, G. B. (1960), Information and Investment: A Study in the Working of the Competitive Economy, Oxford, Oxford University Press.

ROSENBERG, N. (1972), "Factors affecting the diffusion of technology", Explorations in Economic History, vol. 10 (1), p. 3-33.

SCHAPER, M. (2005), Making Ecopreneurs: Developing Sustainable Entrepreneurship, Burlington, VT, Ashgate.

SIM, N. (2006), "Environmental Keynesian macroeconomics: some further discussion", Ecological Economics, vol. 59 (4), p. 401-5.

SIMON, H. (1976), "From substantive to procedural rationality", in S. Latsis (ed.) Method and Appraisal in Economics, Cambridge, Cambridge University Press, p. 129-48.

STILWELL, F. (1974), Australian Urban and Regional Development, Sydney, Australia and New Zealand Book Company. 
VAN BERKEL, R. (2007a), "Eco-innovation: Opportunities for advancing waste prevention", International Journal of Environmental Technology and Management, vol. 7 (5-6), p. 527-50.

VAN BERKEL, R. (2007b), "Cleaner production and eco-efficiency in Australian small firms", International Journal of Environmental Technology and Management, vol. 7 (5-6), p. 672-93.

VERCELLI, A. (1998), "Sustainable development, rationality and time", in Faucheux, S., O'Connor, M. and van der Straaten, J. (eds) (1998), Sustainable Development: Concepts, Rationalities and Strategies, Dordrecht, Kluwer Academic Publishers, p. 259-76.

WACHS, M. and CRAWFORD, M. (1992), The Car and the City: The Automobile, The Built Environment and Daily Urban Life, Ann Arbor, University of Michigan Press.

WORLD BANK (1987), Environment, Growth and Development, Development Committee Pamphlet 14, Washington, D.C., World Bank.

WCED [World Commission on Environment and Development] (1987), Our Common Future, Oxford, Oxford University Press.

WINDRUM, P. and BIRCHENHALL, C. (1998), "Is life cycle theory a special case?: Dominant designs and the emergence of market niches through coevolutionary learning", Structural Change and Economic Dynamics, vol. 9 (1), p. 109-134. 